\title{
A perspective on suicides in the '90s
}

\author{
Philip Meats and Bohdan Solomka
}

\begin{abstract}
We reviowed all 112 suicldes and sell-hom open verdicts in Central Nottinghamshise between 1987 and 1991. The rate of consulfation with generel practitioners af comploted sulcides was similior to control potients a year before decth. If then increased during the succeeding months, particularty in the month belore decath, when $41 \%$ consulted their generel proctitioner. A further $12 \%$ sow conother doctor in theit lost month. Thoes who did not consult were more likely to be middie-aged, molo, divorced or separated, to how experienced a recent broken relationship, and to show evidence of planning the sulcide. Befter owarences moy hove dobected and poselbly provented some suicides in consulters. Those who did not consult a doctor had difterent charactertitles. Additiond stratogies would be needed to prevent these decthe.
\end{abstract}

There has been renewed interest in suicide with the Royal College of Psychiatrists' confidential enquiry into suicides, and the publication of the government White Paper The Health of the Nation (Department of Health, 1992). Prevention of suicide depends on accurate understanding of the factors leading to suicide. Barraclough et als (1974) influential study found that the vast majority of completed suicides were mentally ill and most had had some contact with a doctor in the previous month, so that there was "no lack of opportunities for their suicidal intentions to be recognised and treated". However, since that study there have been changes in the structure of the population and increases in the numbers of younger men committing suicide (McClure, 1987). We therefore set out to obtain a more up-to-date view by examining all suicides within our catchment area, looking at their consulting behaviour, and whether there was any alienation from partners, relatives or others.

\section{The study}

We searched the coroners' records from 1988 to 1991 inclusive, for all suicide, open and misadventure verdicts of residents of our catchment area, and made summaries. The population of $\mathbf{3 0 5 0 0 0}$ lives mainly in small towns, with a third being rural agricultural. As a cross-check we also had available a list of suicides and undetermined injury (ICD E950959 + E980-989) obtained from death certifcate returns to the Director of Public Health. Hospital records were obtained for all those known to psychiatric services, and general practitioner notes were obtained through the relevant Family Health Service Authorities for 101 of the 112 suicides. These were searched for details of contacts with services in the year before death. The main clinical feature of each case was classed as either psychiatric disorder, physical illness or social distress. This was a subjective consensus of all eight consultant psychiatrists. Cases in which social problems were associated with conditions such as chronic depression, alcoholism or personality disorder were classed as psychiatric disorder. We examined the coroners' records for any indications of alienation, looking for breakdown or lack of relationships with family, friends or professionals. Examples included ending of a relationship, divorce proceedings, having no friends, or other evidence of rejection of or by others.

Two control cases were obtained for each suicide for whom we had obtained the GPs' notes. They were drawn from the same practices by searching the age-sex registers for the two closest in age and of the same sex. The notes were searched for the number of face-toface consultations in the year before the death of the index case together with the main symptoms at the latest consultation before the index case date of death.

\section{Findings}

In 87 cases the coroners' verdict was suicide and 25 open verdicts appeared clinically to be suicides, a total of 112 (or 9.2 per $10^{5}$ total population per year). There were 82 men and 
Table 1. Suicides in Central Nottinghamshire 1988-1991*

\begin{tabular}{|c|c|c|c|}
\hline & $\begin{array}{l}\text { Consulited EP in } \\
\text { lost month (n) }\end{array}$ & $\begin{array}{l}\text { Not wen EP in } \\
\text { lost month (n) }\end{array}$ & 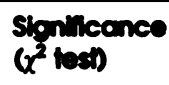 \\
\hline $\begin{array}{l}\text { Total } \\
\text { Sex }\end{array}$ & 54 & 47 & \\
\hline $\begin{array}{l}\text { Male } \\
\text { Fernale }\end{array}$ & $\begin{array}{l}36 \\
18\end{array}$ & $\begin{array}{l}36 \\
11\end{array}$ & NS \\
\hline $\begin{array}{l}\text { Age } \\
15-39 \\
40-59 \\
60+ \\
\text { Chil state }\end{array}$ & $\begin{array}{l}20 \\
15 \\
19\end{array}$ & $\begin{array}{l}13 \\
21 \\
13\end{array}$ & NS \\
\hline $\begin{array}{l}\text { Mariled } \\
\text { Single } \\
\text { Widowed } \\
\text { Divorced/separated } \\
\text { Allenation }\end{array}$ & $\begin{array}{r}28 \\
13 \\
8 \\
5\end{array}$ & $\begin{array}{r}16 \\
13 \\
4 \\
14\end{array}$ & $P=0.04$ \\
\hline $\begin{array}{l}\text { Alencted } \\
\text { Not allencted }\end{array}$ & $\begin{array}{l}19 \\
35\end{array}$ & $\begin{array}{l}26 \\
21\end{array}$ & $P=0.04$ \\
\hline $\begin{array}{l}\text { Recent break-up } \\
\text { Break-up } \\
\text { No break-up }\end{array}$ & $\begin{array}{l}11 \\
43\end{array}$ & $\begin{array}{l}20 \\
27\end{array}$ & $P=0.02$ \\
\hline $\begin{array}{l}\text { Wamings } \\
\text { Given } \\
\text { Not given }\end{array}$ & $\begin{array}{l}23 \\
31\end{array}$ & $\begin{array}{l}17 \\
30\end{array}$ & $r-0.02$ \\
\hline $\begin{array}{l}\text { Planning } \\
\text { Planned } \\
\text { Impulstive }\end{array}$ & $\begin{array}{l}31 \\
23\end{array}$ & $\begin{array}{r}40 \\
7\end{array}$ & $P=0.002$ \\
\hline $\begin{array}{l}\text { Previous dellberate self } \\
\text { Yes } \\
\text { No }\end{array}$ & $\begin{array}{l}24 \\
30\end{array}$ & $\begin{array}{l}12 \\
35\end{array}$ & $P=0.05$ \\
\hline $\begin{array}{l}\text { Reasons } \\
\text { Psychological } \\
\text { Phystcal } \\
\text { Socid }\end{array}$ & $\begin{array}{l}20 \\
13 \\
21\end{array}$ & $\begin{array}{r}12 \\
7 \\
28\end{array}$ & $P=0.11$ \\
\hline $\begin{array}{l}\text { Method of suicide } \\
\text { Overdose } \\
\text { Hanging } \\
\text { Car exhoust } \\
\text { Other }\end{array}$ & $\begin{array}{r}22 \\
17 \\
4 \\
11\end{array}$ & $\begin{array}{r}16 \\
15 \\
10 \\
6\end{array}$ & NS \\
\hline
\end{tabular}

- 101 sulcides for whom GP notes were ovallable

30 women. The mean age was 49 years (range 17-93).

\section{Contacts with psychiatric services}

Fifty of the 112 suicides (45\%) had been known to psychiatric services but some of these had not been seen for up to 16 years. There were only 32 out of 112 (29\%) who had been in contact with services in the last year. The majority of those known to specialist services had been seen by a doctor within the last month (26 out of $32,81 \%)$. The proportion of controls who had ever seen a psychiatrist was much lower at only 11 out of 202 (6\%). Of these, only one was currently an active case and none had been seen in the last month.

\section{Consultations with general practitioners}

The number of suicides who had consulted their GP in the month before death was 42 (41\%) out of the 101 for whom GP notes were available. This was higher than among control patients of whom 34 out of 202 (17\%) had consulted in the month before the index date of death. 


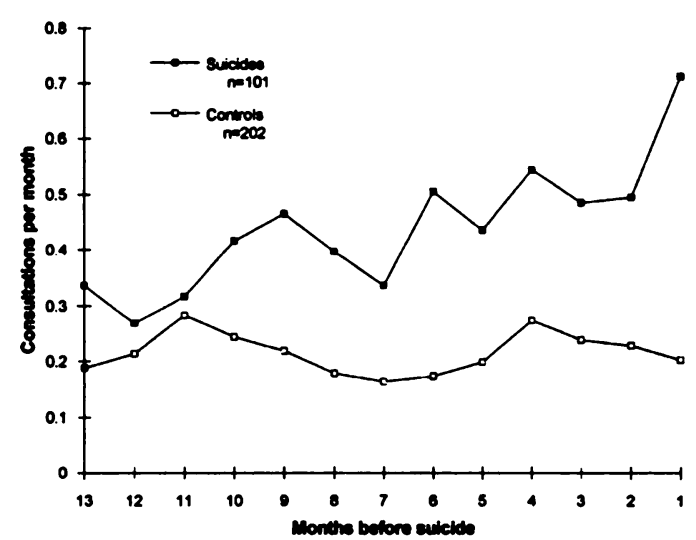

Fig. 1. Number of consultations with general practitioners per month, for the 13 months before death of suicides and matched controls.

Regression lines were calculated wing the method of least squares. The slopes for the two groups were significantly different $(P<0.02)$. Sulcides: slope $=-0.025$ (98\%, $\mathrm{Cl}=-0.039$ to -0.011 ). Controls: slopo $=-0.00016 \quad(98 \%$, $C l=-0.0079$ to +0.0076 ).

The rates of consultation per month were calculated for periods in the year before death for these 101 suicides and their controls (FIg. 1). This shows that the consultation rate for suicides is approximately the same as that of controls a year before death. The consultation rates of controls remain stable throughout the year whereas the suicides consult more frequently as the year progresses with a sharp increase in the month before death.

\section{Consulters and non-consulters}

Forty-two suicides had consulted their GP in their last month, and a further 12 had used either hospital in-patient or out-patient services. Since they had had opportunity to be recognised and thus possibly prevented, this group of 54 'consulters' were compared with the 47 'non-consulters' on a number of variables. Results are shown in Table 1.

\section{Social factors}

Consultation was not significantly associated with age or sex but was associated with marital status and with evidence of social alienation. Two-thirds of those who were married (28 out of 44) consulted in their last month compared with half (13 out of 26) of those who were single and only a quarter (5 out of 19) of those who were separated or divorced. This suggests a correlation between impaired social relationships and reduced likelihood of having consulted a doctor in the last month.

Alienation was rated as including isolation by the subject or rejection by others. Those who had not consulted in the previous month were more likely to show alienation of relationships than those who had consulted $(P=0.04)$. The increase in alienation among non-consulters arose mainly from break-ups with spouses or partners $(P=0.02)$.

\section{Warnings, planning and previous self-harm}

There was evidence of verbal or written warnings, mainly to friends and relatives, of the intention to commit suicide in $40 \%$ of cases. This did not include suicide notes found after the event. There was no significant difference between consulters and non-consulters in the proportion who gave warnings. On the other hand, those who showed some degree of planning were more likely not to have consulted in the last month. Evidence of planning was shown by most of the non-consulters (40 out of $47,85 \%$ ). Nearly half of the consulters had a history of previous deliberate self-harm compared with ony $26 \%$ of non-consulters ( $P=0.05)$.

\section{Reasons}

The primary reason for suicide was classed as intolerable physical illness (20\%), psychological illness (32\%) or social distress (48\%). Examples of 'physical' causes included chronic pain (5), cancer (4) and multiple sclerosis (2). The commonest psychological cause was depression (15) followed by alcohol (6) and psychosis (7). This is not denying that many of those with 'social' reasons were very distressed and depressed, only that the social factors were judged to be primary. Those with a physical or a psychological reason were more likely to have consulted in the last month whereas those with 'social' reasons were less likely to consult.

\section{Comment}

This study shows that people who completed suicide had a normal rate of consulting GPs a 
year before they died and that this increased progressively over the year, particularly in the final month before death. It also shows that those who had consulted a doctor in their last month differed in several ways from those who had not. 'Consulters' were more likely to show other aspects of help-seeking behaviour such as previous contact with specialist services or giving warnings of suicidal intention to others. Non-consulters showed more evidence of alienation and more often had social factors as the prime cause of their distress and suicide. It was arguable in each case whether social factors led to depression and suicide or whether mental illness produced the social defects which caused distress. The assessment of alienation was also based on limited information, and our judgement was subjective. Despite these limitations there is a consistency across the results which suggests that suicides have deficient social relationships and impaired communication with others. Both these factors have been found associated with unexpected suicides of psychiatric in-patients (Morgan \& Priest, 1991).

What pointers are there for the prevention of suicide? Were Barraclough et al (1974) right in claiming that there was "no lack of opportunities" to prevent suicides? Certainly improved education of doctors may prevent some deaths (Rutz et al, 1989). In particular, the presence of impaired social relationships, especially recent separation, should raise the question of suicide risk. Nevertheless, it is dificult to see how general practice and specialist services could prevent suicides among the $46 \%$ who do not consult them. It may be that a proportion of them would have consulted if access to primary and secondary care were easier. However, a public health approach may be more useful. Possible strategies could involve the teaching of social skdlls in school, stress-management classes perhaps available through the workplace or unemployment agencies rather than just health service facilities or better public education and encouraging people to seek help. Another strategy is the reduction of available means of self-destruction. For example, controls on the levels of carbon monoxide in car exhaust have been introduced in the United States with a corresponding reduction in deaths from car exhaust and without a switch to other means of suicide (Clarke \& Lester, 1987). Given a range of such initiatives then the Health of the Nation targets of a 33\% reduction in suicides in the severely mentally 111 and $15 \%$ in the general population by 1999 may be achievable.

\section{Acknowiedgements}

Thanks are due to the coroners clerks in Nottingham and Chesterfield who made us welcome; to Dr Chris Packham for helpful advice; and to Julie Harris and Carol Hall for their help.

\section{References}

BArRaclough, B., Bunch, J., NELSON, B., et al (1974) A hundred cases of clinical suicide: clinical aspects. Brttish Joumal of Psychiatry, 125, 355-373.

Clarke, R. V. \& Lestrer, D. (1987) Toxicity of car exhausts and opportunity for suicide: comparison between Britain and the United States. Joumal of Epidemiololgy \& Community Health, 41, 114-120.

DEPARTMENT Or HEALTH (1992) The Health of the Nation. strategy for health in England. London: HMSO. (Cm 1986).

MCCure, G. M. G. (1987) Suicide in England and Wales, 1975-1984. British Joumal of Psychiatry. 160, 309-314.

MoranN, H. G. \& Prasst, P. (1991) Sulcide and other unexpected deaths amongst poychiatric inpatients. The Bristol confidential inquiry. Brttish Joumal of Psychiatry, 168, 368-374.

RUTZ, W., VON KNORRING, L. \& WAINDER, J. (1989) Frequency of suicide on Götland after systematic postgraduate education of general practitioners. Acta Psychiatrica Scandinavica, 80, 151-154.

*Philip Meats, Consultant Psychiatrist; and Bohdan Solomka, Registrar in Psychiatry, Mullbrook, King's Mul, 'Sutton-in-Ashfield, Nottinghamshire NG17 4JT

"Correspondence 